\title{
Green treasures and paper floras: the business of Mutis in New Granada (1 783-I 808)
}

\author{
José Ramón Marcaida' and Juan Pimentel ${ }^{\mathbf{2}}$ \\ I Universidad de Deusto, Bilbao, Vizcaya, Spain \\ ${ }^{2}$ Instituto de Historia, Consejo Superior de Investigaciones Científicas (CSIC), Spain
}

\begin{abstract}
This paper explores the endeavours of José Celestino Mutis before and during his directorship of the Royal Botanical Expedition to the New Kingdom of Granada (1 7831816). Firstly, it will consider various aspects of Mutis' activities as a naturalist and entrepreneur, in particular his efforts to promote the identification and commercial exploitation of three natural products associated with the Viceroyalty of New Granada: quina, cinnamon, and tea. Secondly, the paper will focus on the complex dynamics of the expedition's artistic workshop, whose outcome was the monumental compilation of botanical illustrations known as the Flora de Bogotá. The overall aim is to offer a reflection on the challenges posed by the practices of accumulation and management in the context of a scientific expedition inspired by the new policies of the reformist movement in Spain and designed to make profit out of the nature of the New World and its knowledge.
\end{abstract}

\section{Keywords}

mimetic capital, Mutis, natural history, New Granada, quina, scientific expedition

His dream began to fall apart the same day it was fulfilled.

Gabriel García Márquez, El general en su laberinto, Bogotá, Editorial Oveja Negra, 1989, p. 158.

\footnotetext{
Corresponding author:

José Ramón Marcaida, Facultad de Ciencias Sociales y Humanas, Universidad de Deusto Avenida de las Universidades, 2448007 Bilbao, Vizcaya, Spain.

Email: joserra.marcaida@gmail.com
} 


\section{The 'green rush' of Spanish imperial science}

In 1762 the Spanish statesman Pedro Rodríguez de Campomanes, working in the service of King Charles III, penned his Reflections on the Spanish Trade with the Indies. ${ }^{1}$ This text, which remained unpublished during its author's lifetime, dealt with a highly controversial and long-debated question: the neglect of the Spanish metropolis with respect to its overseas territories. Like many of his contemporaries, Campomanes was convinced that instead of getting wealthier through the exploitation of its vast New World dominion, Spain had become poorer as a consequence of it. Far too many resources had been devoted to the extraction of precious metals, whose accumulation not only was transitory - for they ended up in foreign hands due to the crown's debts but had distracting effects on the economic forces on which the true wealth of the nation depended: industry, agriculture and trade. Thus, Campomanes questioned the basic principles of bullionism, according to which the wealth of a nation would be measured by its stock of precious metals. Another excruciating problem affecting the government of the Indies, in his view, was 'having relinquished the writing of the natural and geographical history of America and its traditions, so the nation becomes aware of its products'. ${ }^{2}$ Years later, Alejandro Malaspina, the commander of the most complete scientific expedition of the Spanish Enlightenment (1789-1794), slightly more audacious than Campomanes with regard to his proposed reforms, agreed with the statesman on the nature of the maladies affecting the empire. He also denounced 'the excessive silver zeal' and argued for the development of science. 'Without knowing America', Malaspina wrote, 'how is it possible to govern it?'3

The Spanish reformist movement attempted to replace the old colonial model with a more rational and profitable plan, a plan based on the substitution of the object of accumulation: knowledge instead of metals. Rather than amassing gold and silver, the aim now was to encourage the accumulation of knowledge of American commodities in order to promote their circulation and trade. Between 1765 and 1789, Spanish reformers tried to reorganize the structure of the empire: novel administrative units were created (the intendencia) and trade was moderately liberalized; also, commercial consulates as well as new companies were founded. The metropolis struggled to turn its possessions into a market for their products and a source for its industry, i.e. the classic division of labour propitiated by the accumulation of capital, but on an international scale. In sum, a new version of the colonial pact was sought, one closer to the British, French and Dutch models than the one inherited from the Baroque monarchy. ${ }^{4}$

As part of this new colonial policy, Spain launched an ambitious programme of scientific expeditions to America and the Pacific Ocean, comprising a wide range of geographic and hydrographical explorations, ethnographic surveys, and naturalist investigations, for the period of over three decades. Botanical expeditions, in particular, acquired a renewed importance as part of this new agenda. Whereas gold and silver did not seem to contribute to the 'wealth of the nation', Spain could rely on one of the largest green capitals of the planet: America. ${ }^{5}$ Writing at the beginning of the century, the explorer Louis Feuillée had described the plants of South America as 'far more valuable treasures than those that are extracted from the mines of Peru' ${ }^{6}$ Fifty years later, the rise of the Linnaean system, the influence of French physiocracy on Spanish economic 
thought, and an awareness of the dangers associated with the monopoly policy, intensified the interest of the Spanish authorities in what could be characterized as the new El Dorado, a 'green' El Dorado. ${ }^{7}$ Plants, particularly those with medicinal properties, but also spices and foodstuffs, could become true 'remedies for the empire', to paraphrase Mauricio Nieto's expression. ${ }^{8}$ Consequently, a sort of 'green rush' took command of the reformers' agenda: they hoped products like quina, cinnamon, pepper, grana or indigo would counteract the negative effects that gold and silver had had on the health of the empire. In this regard, Casimiro Gómez Ortega, director of the Royal Botanical Garden of Madrid, and one of the standard-bearers of this new policy, wrote that 'twelve naturalists, with as many chemists or mineralogists spread throughout the state, would produce with their peregrinations an incomparably larger utility (utilidad) than a hundred thousand fighting men'.

As a result of these policies, and coordinated by the Botanical Garden together with the Cabinet of Natural History and other metropolitan institutions, a number of botanical expeditions were sent to the four corners of the empire: Hipólito Ruíz and José Pavón directed the explorations of Peru and Chile (1777-1815); Martín Sessé and José Mociño supervized the expedition to New Spain (1787-1803); Juan de Cuéllar was in charge of the Philippines (1786-1797); and José Celestino Mutis, whose activities will be the subject of this paper, directed the expedition to New Granada (1783-1808) (Figure 1). The objectives were to explore the territory, classify botanical species, assemble herbaria and collections and send them to the Botanical Garden or the Cabinet of Natural History and, most importantly, to study the properties and local uses of natural products, in order to promote and maximize their commercial exploitation. ${ }^{10}$

However, the metropolitan plan to accumulate knowledge of that 'green treasure' faced a long list of obstacles: the rigours of long-distance voyaging; the conflicts between the main participants and the large number of institutions involved; and, more generally, the inherent difficulties associated with the generation and circulation of scientific knowledge - a highly versatile and polyvalent material, but less portable and measurable than it is generally assumed. For even if the products of science are mobile, this does not render science immutable: every move, every displacement, carries alterations with it, and managing these fluctuations in the context of 18th-century science turned out to be a highly sophisticated task. ${ }^{11}$ The story of Mutis and the New Granada expedition constitutes an illuminating case study in this regard. ${ }^{12}$

\section{Mutis and the Royal Expedition to the New Kingdom of Granada}

It seems rather curious to keep characterizing Mutis' one-way journey to New Granada as a 'scientific expedition' - an expression somehow marked by a strong Eurocentric bias. Born in Cádiz in 1732, in 1760 Mutis set out on a trip to Cartagena de Indias, never to return. At the time he was not involved in any botanical mission, but travelled as the personal physician of the newly appointed viceroy of the New Kingdom of Granada, Pedro Messía de la Cerda. Mutis had studied surgery at the College of Surgery in Cádiz and medicine at the University of Seville. Later on, he worked for the chair of anatomy 
at the General Hospital of Madrid, and in the 1750s paid regular visits to the Botanical Garden, an institution situated halfway between the ancient materia medica and the legacy of Joseph Pitton de Tournefort; that is, marked by out-of-date ideas and practices. A rather negative testimony written by Mutis himself provides a contemporary description of the Botanical Garden and the Cabinet of Natural History, the two institutions on which the programme of scientific expeditions would eventually be based:

Wise and curious men, travelling through all the courts in Europe, hoping to find in Madrid a sumptuous and magnificent garden and cabinet of natural history, splendidly ornamented with all the plants and precious bodies produced by the New World, admire nothing but the shadows of a garden and a cabinet whose construction began during the reign preceding your Majesty's. ${ }^{13}$

Acutely aware of the benefits that an aptly designed programme of economic botany would have for the nation, Mutis got fixated on natural history as the means to channel and realize his intellectual and entrepreneurial ambitions. ${ }^{14}$ This interest exacerbated on the occasion of his voyage to America, for it was there where Mutis began to take great care over the practice of botany, and set various initiatives in motion associated with the exploitation of natural knowledge and natural products.

Having settled in Santa Fe de Bogotá - where he arrived in 1760 - Mutis applied for the viceroy's support with the idea of putting together a naturalist project. He did not succeed. Years later, in 1763 and 1764, he sent two almost identical memoriales to the king, in which he not only described the lack of institutional vigour in the peninsula, but also called attention to various American natural products - quina, cinnamon, cochinilla, guayacan - and asked for the crown's support to finance his plans to exploit them while in New Granada. In these documents Mutis would introduce himself as the heir of Francisco Hernández, the illustrious Spanish physician who, in the 1570s, had directed one of the most important expeditions to the New World. ${ }^{15}$ Mutis was ambitious and audacious indeed. In the memoriales he would also present himself as Pehr Löfling's successor, in reference to Carl Linnaeus, his master. It is worth mentioning that in 1760 Mutis had penned his first botanical description following an edition of Linnaeus' Philosophia botanica purchased from Frédrik Logié, one of the Swedish naturalist's disciples, in Cádiz - where he had also met Clas Alströmer, another of Linnaeus' students, a businessman specialized in the acclimatization of plants. In this regard, as someone dutifully concerned about systematization and nomenclature but much more attentive to the state-funded commercialization of natural resources and other initiatives derived from the nation-nature pairing, Mutis too could be characterized, at this stage, as an aspiring, self-taught Linnaean - following Lisbeth Koerner's account of this term. ${ }^{16}$ Eventually, Mutis would end up corresponding with the famous naturalist, to the point that his dispatches of specimens and information earned him not only the customary acknowledgement of having the mutisia genus named after him, but also a fair amount of sought-after credit and reputation. ${ }^{17}$

In spite of the king's silence and the lack of funding, the ever tenacious Mutis started working on his various naturalist projects, including the compilation of botanical descriptions and illustrations that eventually would form his Flora Bogotensis or Flora de Bogotá. This was done in a rather unsystematic way: Mutis had to rely on his own 
resources, while devoting himself to other ventures. For instance, in 1766 he acquired shares of the company running the silver mine of Montuosa, in the province of New Pamplona, Northeast of Santa Fe. When the company went broke, Mutis returned to the capital and practised medicine for a while. In 1772 he was ordained as a priest. A few years later, he tried silver mining again: in 1777 he moved to Ibagué, and from there he took part in the exploitation of the mine of El Sapo. During this time - until 1783, when his proposals were finally given the official go-ahead - Mutis did not put his other scientific interests aside. In addition to collecting botanical specimens, writing their descriptions and having their illustrations made, he also studied mathematics and physics, gathered notes about New World fauna, and even carried out a notable study of ants. ${ }^{18}$

Mutis' engagement in such a varied array of activities was by no means exceptional, as many contemporary naturalists found themselves involved in similarly wide-ranging endeavours - including Linnaeus, truly a 'Jack-of-all-trades', to use Koerner's expression. ${ }^{19}$ However, reflecting on Mutis' naturalist project as a whole, José Antonio Amaya, one of his best biographers, noted that it was 'too ambitious as a dream for someone like him, independent of institutions and isolated from the colonial world'. ${ }^{20}$ As a consequence of this, and 'for lack of a better strategy', Amaya added, Mutis limited himself to 'accumulating descriptions, herbarium sheets, drawings and books'. ${ }^{21}$ What is implied by this characterization of Mutis' efforts in terms of 'accumulation'? How can it contribute to an understanding of the context in which his and other naturalists' projects were developed? At another level, how does the category of 'centre of accumulation and management' fit into the Mutis story? Which lessons can be drawn from its use?

This paper will attempt to answer these questions by taking Mutis' endeavours and the New Granada expedition as the main motifs. Firstly, it will consider various aspects of Mutis' activities as a naturalist, in particular his efforts to promote the identification and exploitation of three American products: quina, cinnamon, and tea. Secondly, the paper will focus on the dynamics of the expedition's artistic workshop as a manifestation of the complex tension between the exercise of accumulation and the pertinence of management. The overall aim - which may be helpful to analyse other case studies associated with the American colonial scenario - is to offer a reflection on the challenges posed by the practices of accumulation and management in connection with the tasks of making sense of and making money out of the nature of the New World.

\section{The business of Mutis in New Granada}

In 1783 Mutis was granted the long-awaited directorship of a state-funded botanical expedition. The previous year he had become acquainted with the bishop Antonio Caballero y Góngora, the newly appointed viceroy of New Granada, whose sponsorship would prove to be a determining factor of Mutis' success in obtaining royal support.

Mutis' interests in the commercialization of natural products lay at the core of this project. This was in line with Spanish ambitions regarding the capitalization of the green El Dorado - which saw the Botanical Garden, under the direction of Casimiro Gómez Ortega, become the headquarters of a sort of 'botanical reconquista' ${ }^{22}$ Just like Gómez Ortega, Mutis got interested in the study and exploitation of three specific products: quina, cinnamon and tea. A quick glance at Mutis' handling of these categorization and 
commercialization projects brings to light the kind of conflicts and tensions associated with the early globalization and the primitive accumulation of capital. ${ }^{23}$ Similar kinds of conflicts and tensions would also characterize the practice of science, given the contested and negotiated nature of knowledge production and circulation - or 'dispersion', to quote from Lissa Roberts' discussion of this term in this issue.

Let us begin with the case of quina, the 'bitter gold' ('oro amargo'). ${ }^{24}$ Its antipyretic properties had been known in the Old World since the 17th century, but it was the French explorer and polymath Charles Marie de La Condamine who situated it on the map of European science. ${ }^{25}$ Following the geodesic expedition to Peru, in which he was involved, La Condamine wrote the description of a kind of quina from the region of Loja (present Ecuador) and published it in the Mémoires de l'Académie Royale des Sciences in 1738. Linnaeus used this description to include the Cinchona officinalis in the second editions of Genera Plantarum (1742) and Especies Plantarum (1753). However, in 1764 Mutis sent Linnaeus a desiccated sample from the region of Santa Fe, situated farther north. It was a different kind of quina, which forced Linnaeus to modify his account. The latter kind was named cinchona cordifolia, while the first came to be known as cinchona condaminea or lancifolia. As Mauricio Nieto has argued, rather than describing a species, Linneaus fabricated it using several descriptions, a classic example of the circulation and social construction of knowledge. ${ }^{26}$

On top of the taxonomical disputes on the different types of quina there came the debates regarding their curative properties. Could all be used as remedies against intermittent fevers? Did they work with the same efficacy? Were the species originating from north of the Equator equal to the ones originating from the South? A priori, the genuine cinchona came from the region of Loja, but the indiscriminate deforestation in the province led to an awareness, half way through the century, of the dangers of depletion. As a consequence, quina dealers began to trade with species of different origins, under the cinchona officinalis designation. Smuggling and fraud - two practices characteristically associated with the accumulation of either resources or information - flourished.

Mutis' contributions to the study of quina should be considered in this context, a context marked by the quest for recognition on the part of the naturalists, disputes over priority of discovery, commercial interests of the merchants from Peru and New Granada, and the aspirations of the metropolitan authorities. Mutis was involved in such controversies with two naturalists who called into question his being the first one to identify quina in the forests of New Granada. On the one hand, Miguel Santiesteban, who found cinchona trees in Popayán in 1752, and joined Mutis on the surveys where the latter claimed to have found these trees for the first time (1764). On the other, Sebastián José López Ruiz, a physician from Panama, with whom Mutis held a similar dispute a decade later concerning the samples found in the vicinity of Santa Fe. ${ }^{27}$ This second confrontation was aggravated by the fact that Gómez Ortega granted López Ruiz the directorship of the botanical expedition to New Granada (1778-1783), the favour that Mutis had been claiming for himself ever since his arrival in America.

In those years, the 1780s, the conflict surrounding the exploitation and trade of quina radicalized. The merchants from Guayaquil, the most important seaport in the Quito Audiencia - an administrative unit which then belonged to the Viceroyalty of New Granada - saw their interests threatened if the quina of New Granada was considered to 
have the same quality as the one from Loja. Shipments of different species were sent to Madrid for analysis and validation, but the Andean dealers did not accept the conclusions reached by the chemists working at the Royal Pharmacy. As Matthew Crawford has put it, 'while the bark moved quite easily, knowledge did not'. ${ }^{28}$ According to him, subsequent projects devoted to the quina trade reveal a more complex interaction than the simple opposition between a metropolitan science and a patriotic epistemology. ${ }^{29}$ Some criollos wanted to maintain the existing distribution system - a system based on the acquisition of goods in exchange for an agreed upon share of the quina production while others demanded the crown's intervention.

Several reports were commissioned with the idea of establishing a royal monopoly (estanco) of quina. Santiesteban and López Ruiz wrote two of them before Mutis penned his own, entitled Real Proyecto del estanco de la Quina y sus establecimientos (1786). ${ }^{30}$ In this text Mutis argued for a state-owned business run by the Real Hacienda which would be in charge of the administration and distribution of quina. He deemed it necessary to accumulate large stocks in order to avoid shortage and price speculation. Besides this, the existing arrangement involving different competing landowners had to cease, since it was causing all sorts of trouble: the lands were left exhausted ('a quina tree in Peru will end up being as rare as one in Norway'); the shipments destined for Europe were hastily prepared and lacked proper control; once in Cadiz cargoes piled up while in America a great proportion of stock was wasted. In sum, the cultivation and traffic of quina had to be put in order.

Mutis' viewpoint was linked to local interests, which included his own personal ambitions. Between 1785 and 1788 - the period during which the production of quina in New Granada boomed, with export taxes equal to those in the Quito region - Mutis traded with producers and accumulated stocks of quina in two factories in the city of Mariquita and the neighbouring town of Honda. He may even have been involved in the black market, once the Spanish crown abandoned the royal estanco project; this was not an infrequent practice at the time, for half of the production of quina was smuggled. ${ }^{31}$ Mutis' personal businesses, in sum, became entangled with the crown's projects to cash in on the 'bitter gold'.

In 1789 the crown decided to put an end to shipments coming from New Granada and the project of a quina estanco was abandoned. Mutis still had time to publish a set of observations in the Diario (1793), which would later appear posthumously under the title El Arcano de la quina (1828)..$^{32}$ His disputes over this matter with Hipólito Ruiz and José Pavón, directors of the botanical expedition to Peru (1777-1815) and Gómez Ortega's loyal allies, continued well into the 19th century. Underlying these controversies regarding taxonomy and materia medica lay hidden the business interests of local, landowning elites; for this was a place, as Humboldt would put it, in which 'physicians, like popes, drew the lines of the map'. ${ }^{33}$

The two projects designed to exploit and trade with American cinnamon and Bogotá tea - two products with which Spain hoped to break the monopoly of Ceylon cinnamon and Chinese tea, controlled by the Dutch and English respectively - shared similar features. As in the case of quina barks, the members of the geodesic expedition to Peru had informed about the existence of cinnamon trees in the provinces of Maynas and Quijos, in the border between the Quito and the New Granada Audiencias. ${ }^{34}$ In his 1760 s 
memorials, Mutis mentioned the possibility of their exploitation, and very soon similar species were discovered in New Granada. Despite being different from the one in Ceylon (this lauracea was not a cinamonum), the medicinal properties and aromatic virtues of the American cinnamon, according to Mutis, were noteworthy. So it was that he had seeds and trees brought from the forests south of the viceroyalty to his hacienda in Mariquita. Once these trees became acclimatized, Mutis sent samples of their fruits to the Royal Pharmacy of Madrid, for chemical analysis. There the notable differences between this and the Oriental species were revealed. In the light of these results, Gómez Ortega showed a mild interest in American cinnamon, favouring the one from Peru rather than the one from New Granada. To make matters worse, the work of Joseph Dombey showed the lesser value of Peruvian cinnamon, bringing the discussion to an end. In the 1780s, while Mutis tried to cultivate cinnamon trees in Mariquita, the metropolitan expectations changed, and focused on the Philippines, where another naturalist, Juan de Cuéllar, was sent to explore. The latter's writings and botanic activities would constitute the last attempt on the part of Spain to compete with the Dutch monopoly. ${ }^{35}$

Also a combination of great hopes and aborted initiatives, the project designed to exploit the tea of Bogotá (alsthonia theiformis) suffered a similar fate. In 1781 Mutis had communicated to Linnaeus' son the existence of this tea; later on, in 1785, he informed the Viceroy Caballero y Góngora and the Spanish ministers José de Gálvez and the Count of Floridablanca. Again, Mutis presented the discovery of American tea and its potential commercialization as a contribution to 'the glory of the Spanish nation'.${ }^{36}$ The following year he had this species cultivated in Mariquita, and arranged for the accumulation of stock in Honda. Several samples were sent to the Royal Pharmacy of Madrid for evaluation, and the first reports were positive. Given these results, in 1788, when the project to set up a quina estanco lost its momentum, Mutis focused on the cultivation of tea of Bogotá instead. The project, however, did not succeed. In 1790 the shipments were ordered to stop, on the basis that further analyses performed at the Royal Pharmacy had yielded conflicting assessments. Eventually, the judgement of those opposing the promotion of the tea of Bogotá - according to whom Chinese tea was considered to be of superior quality - prevailed. Thus, the dream of setting up minimally prosperous businesses in New Granada came to an end - and so did the hope of competing against the Dutch and English monopolies.

What preliminary conclusions can be extracted from these events? On the one hand, programmatically at least, the Spanish government seemed to have tried to shift from a mercantilist model dependent on the accumulation of precious metals to one focused on medicinal products and foodstuffs. ${ }^{37}$ With regard to this attempted transition it could be argued that the shift was less real than rhetorical, since not even the Decree of Free Trade of 1778 - celebrated by historians of liberalism as a true turning point - carried with it a transformation of the colonial pact. Moreover, it was not a realistic plan, since the Spanish trade with the Indies before 1750 had been heavily centred around the importation of metals, dyes and textile products, rather than goods related to materia medica. In this regard, the projects designed by the Botanical Garden looked like mere 'office documents'. ${ }^{38}$ In addition to this, plans such as the quina estanco or the royal monopolies of cinnamon and tea were marked by halfway measures and transitional strategies. To a great extent, they could be regarded as a new kind of bullionism, a mercantilism focused 
on highly specific natural products - quina, cinnamon and tea - which were meant to replace gold and silver.

On the other hand, it should be noted that, as in the case of other projects launched in other parts of the globe, these schemes devoted to the successful acclimatization and cultivation of species in New Granada were plagued with epistemic as well as political problems. ${ }^{39}$ Indeed, the disputes over the advantages of one variety over others mirrored the regional rivalries that soon would mark the fate of post-independence Latin America. On a more positive reading, though, an important consequence of these schemes - and the subsequent proliferation of centres of accumulation and management derived from their being put into practice - was a reinforcement of the intellectual life in the viceroyalty and the revitalization of scientific culture at a local level, reflected in the promotion of educational institutions and printing presses, many of which had been active since the 16th century, as well as learned journals and salons. Indeed, while the economic botany promoted in New Granada may not have yielded the kind of results required to enrich the viceroyalty and the metropolis, and allow them to compete with the global markets, it did contribute to strengthening and furthering local cultures of science. In the case of the New Granada expedition, for instance, it should be noted that it was there where many members of what later would be regarded as the scientific elite of the viceroyalty (Caldas, Zea, Valenzuela, Matis) got their training and perfected their skills.

Finally, we should not leave aside the personal careers of individuals like Mutis, who were led to play different roles - naturalists, courtiers and entrepreneurs - in their quest for knowledge, power and commercial benefits. Mutis had to act - and so he did - in various networks simultaneously: the creole elites in the viceroyalty, his own collaborators, the correspondents of Linnaeus, the crown officials, etc. He belonged to many circles, rather than one in particular, a fact that granted him -following Georg Simmel - many opportunities for individualization. ${ }^{40}$ In the next section we will pay close attention to these by examining one specific aspect of his naturalist endeavours.

\section{Mutis' paper Flora: the accumulation and management of mimetic capital}

Amounting to more than 7000 illustrations - including thousands of colour and monochrome botanical portraits as well as hundreds of elaborate floral anatomies - the extant corpus of images generated by the Royal Botanical Expedition to the New Kingdom of Granada is the largest of all picture compilations produced by any 18th-century Spanish expedition. ${ }^{41}$ The visual culture around this project, the Flora de Bogotá, has been the subject of a number of exhibitions and academic studies. ${ }^{42}$ For the purpose of this paper, Daniela Bleichmar's account of Mutis' expedition as part of a larger programme of 'visualization projects' aimed at making the Spanish empire not only 'visible' but also commercially 'profitable' has proven the most valuable and inspiring source. ${ }^{43}$ In Bleichmar's view, Mutis' interest in expanding the 'iconographic vocabulary' of American natural history led him to considerable efforts to establish a solid and stable procedure of botanical investigation and natural illustration. This effective combination of 'botanical eyes' 
and 'skilful hands', she claims, allowed Mutis to explore the limits of the highly standardized pictorial conventions of 18 th-century natural history, to the point of developing a unique representational style. ${ }^{44}$

Mutis, indeed, privileged visualization to such an extent that the production of images eventually became the most important aspect of his expedition in terms of material and personal investment. The large number of artists involved provides a good measure of the project's imposing dimensions: over a period of three decades more than 50 painters were employed, many of them working simultaneously at various points - the first seven years, from 1783 until 1790, were spent in the town of Mariquita, and the remaining years, from 1790 until 1819, in the capital, Santa Fe de Bogotá. ${ }^{45}$ Overwhelmed by the number of specimens collected by the expedition's herbolarios, Mutis constantly felt the need to expand the personnel employed in his artistic workshop. So large was the number of new plants, he wrote in March 1783, that 'many painters would not be idle for several years'. ${ }^{46}$

From a managerial perspective, this material overload gave rise to a number of problems: how to coordinate fieldwork and workshop activities, how to train and supervise apprentice artists, and, more generally, how to maximize productivity under such constraints as the fragile nature of botanical specimens, on the one hand, and the meticulous elaboration of illustrations, on the other. In the face of these organizational challenges, Mutis found the solutions that best suited his ambitious programme. On the one hand, given the vast amount of information that needed to be processed, the production of images adopted a carefully designed procedure which could involve several artists working on different aspects of the same illustration: from the preliminary sketch of a plant, in pencil, to its coloured depiction, using tempera. The result of this highly controlled process - based on a technique described by Mutis as 'pintura al temple en papel' - was a model of botanical illustration intended to provide the naturalist with all the information required to identify and classify a given specimen according to the Linnaean system.

Another key strategic move, on the other hand, was the decision to establish a free drawing school ('escuela de dibujo') at the service of the expedition. Both at Mariquita and Santa Fe de Bogotá, the school was directed by the Cartagena-born painter Salvador Rizo, who had joined the expedition in 1784 and worked not only as its 'primer pintor' - after the departure of Pablo Antonio García, Mutis' firstly appointed official painter but also as its 'mayordomo', an important administrative position. ${ }^{47}$ The free school fulfilled a twofold goal. The first was to attract enough apprentices in the art of botanical illustration, who could be then hired to work for the expedition and keep the artistic workshop functioning. The second was to attract the right type of apprentices, according to Mutis' criteria: young, docile and compliant students, more open to learning than elder and well-established artists. ${ }^{48}$ Handling these untrained but skilful pupils allowed Mutis to customize their technique and thus preserve the desired style and quality of execution throughout the duration of the expedition.

This capacity to assemble and sustain, i.e. to accumulate and manage, a team of mostly American artists for such a period of time, scholars agree, constitutes a unique feature of the New Granada expedition. ${ }^{49}$ It is also rather illuminating with respect to Mutis' attitudes as the project's chief director, particularly regarding his views on the 
overall potential of the expedition's artistic workshop. Following a strictly controlled procedure, and adopting a clearly defined model of representation, the expedition could hope to produce a pictorial reproduction of the entire flora of New Granada. ${ }^{50}$ Very early this proved to be an overly ambitious plan, and yet the large corpus of illustrations generated by the expedition demonstrates Mutis' organizational ability to face the challenge: during the first seven years spent in Mariquita, a team of 11 artists managed to produce several hundred images; and over the following years, with the expedition settled in Santa Fe de Bogotá, a much larger workshop ended up producing more than 5000 illustrations. ${ }^{51}$ Hence, through watchful management and an appetite for boundless accumulation, Mutis managed to turn the New Granada expedition into an increasingly productive image-making (that is, a knowledgemaking) enterprise.

The benefits from such an investment would be many, Mutis would claim. The high quality of the expedition's botanical illustrations, in particular, was to render future exploration voyages to New Granada unnecessary, for these materials, the Florae Bogotensis, would convey all the required information for identification and classification purposes. ${ }^{52}$ But there was another side to this epistemologically sound dynamism driving the project forward: possession. For Mutis, as for his contemporaries, image-making was a form of appropriation to the extent that it granted a continuous access to a given natural object, thus favouring its eventual analysis, manipulation and exploitation.

Mutis' efforts to capture and possess New Granada flora by pictorial means may be interpreted as a form of appropriation mediated by what Stephen Greenblatt, adapting Marx, has termed 'the reproduction and circulation of mimetic capital'. ${ }^{53}$ This expression, by which he refers to 'the stock of images, along with the means of producing those images and circulating them according to prevailing market forces', evokes a key aspect of botanical illustration - its capacity to portray vividly a given natural object - as well as the characterization of American nature as a commodity derived from the Marxian discussion on the 'previous' or 'primary' accumulation of capital in connection with New World goods. 54

To a large extent, Greenblatt's account of the magnitude of present-day, capitalistdriven circulation of mimetic capital fits with Mutis' approach to 18th-century natural illustration insofar as it highlights 'the will and the ability to cross immense distances and, in the search for profit, to encounter and to represent radically unfamiliar human and natural objects'. Moreover, the expression conveys the sense of 'a stockpile of representations, a set of images and image-making devices that are accumulated', which echoes Mutis' ever growing stock of botanical illustrations. According to Greenblatt, the images that deserve the term 'capital' are those that feature a 'reproductive power, maintaining and multiplying themselves by transforming cultural contacts into novel and often unexpected forms', ${ }^{55}$ an effect which in the case of the New Granada expedition was partially achieved by the conscientious development of a new representational style. Both in Mariquita, and later in Santa Fe de Bogotá, the expedition's artistic workshop would replicate the multi-directional trajectory that Greenblatt attributes to mimetic circulation: 
... first, representations and the particular technologies that generate them are carried from place to place, most often moving according to the logic of conquest and of trade though occasionally swerving in unforeseen directions, propelled by perversity or accident; second, those who receive representations from elsewhere themselves move, with greater or lesser freedom, among a range of images and techniques simultaneously available in their culture. ${ }^{56}$

The vast compilation of images orchestrated by Mutis, together with the development of a novel representational style, would have had a much more significant impact on both local and foreign perceptions of American natural history had the corpus of illustrations been published as planned. The images, however, remained in Mutis' hands until he died - despite persistent requests on the part of the Spanish authorities. The subsequent appropriation of this material (both physical and symbolic) was the subject of much controversy, as we will see. The Flora de Bogotá was truly an iconographic treasure, the most important outcome of the expedition. Not only did the new style provide these images with a unique 'American' character: their large number, together with the technical difficulty of making them reproducible turned them into an exceptional, irreplaceable possession.

\section{The risky business of accumulation}

Mutis endeavoured to construct an image of himself as a qualified and resourceful naturalist, whose expertise in all matters of natural knowledge and commodification could help the Spanish crown to fulfil its ambitious programme of American reconquista. In this regard, his ability to turn the New Granada expedition into an active centre of accumulation and management was undoubtedly among his most remarkable accomplishments. Mutis' attitude, however, cannot be fully understood without considering his own aspirations both as a naturalist and entrepreneur. In other words, his willingness to become an active member of the imperial network cannot be separated from his own interests in the local circles, where he also saw himself as a qualified and skilful agent. His story, then, like that of many of his contemporaries, is not one of polarized desires and irreconcilable commitments - imperial utility versus personal gain, intellectual benefit versus commercial profit, governmental initiative versus individual determination, etc. - but, rather, one of entangled interests and convoluted practices, which more often than not would result in tensions and conflicts.

A good example of this concerns one of Mutis' most valuable undertakings: the formidable corpus of botanical illustrations produced during the expedition, which, as has been noted already, remained unpublished during his lifetime. A partial explanation to this complex case of accumulation and (mis)management would be, quite paradoxically, its own success as an image-making enterprise: Mutis succeeded in organizing and implementing an efficient and stylistically distinct visualization procedure, but failed to manage its outcome; or, at least, to manage it in line with the expedition's objectives, which included the eventual editing and publication of these visual materials.

Let us briefly consider Mutis' dealings with his image-making project. On the one hand, he frequently relied on the expedition's images to win over influential patrons and please illustrious colleagues, and, more generally, to feed the voracious dynamics of 


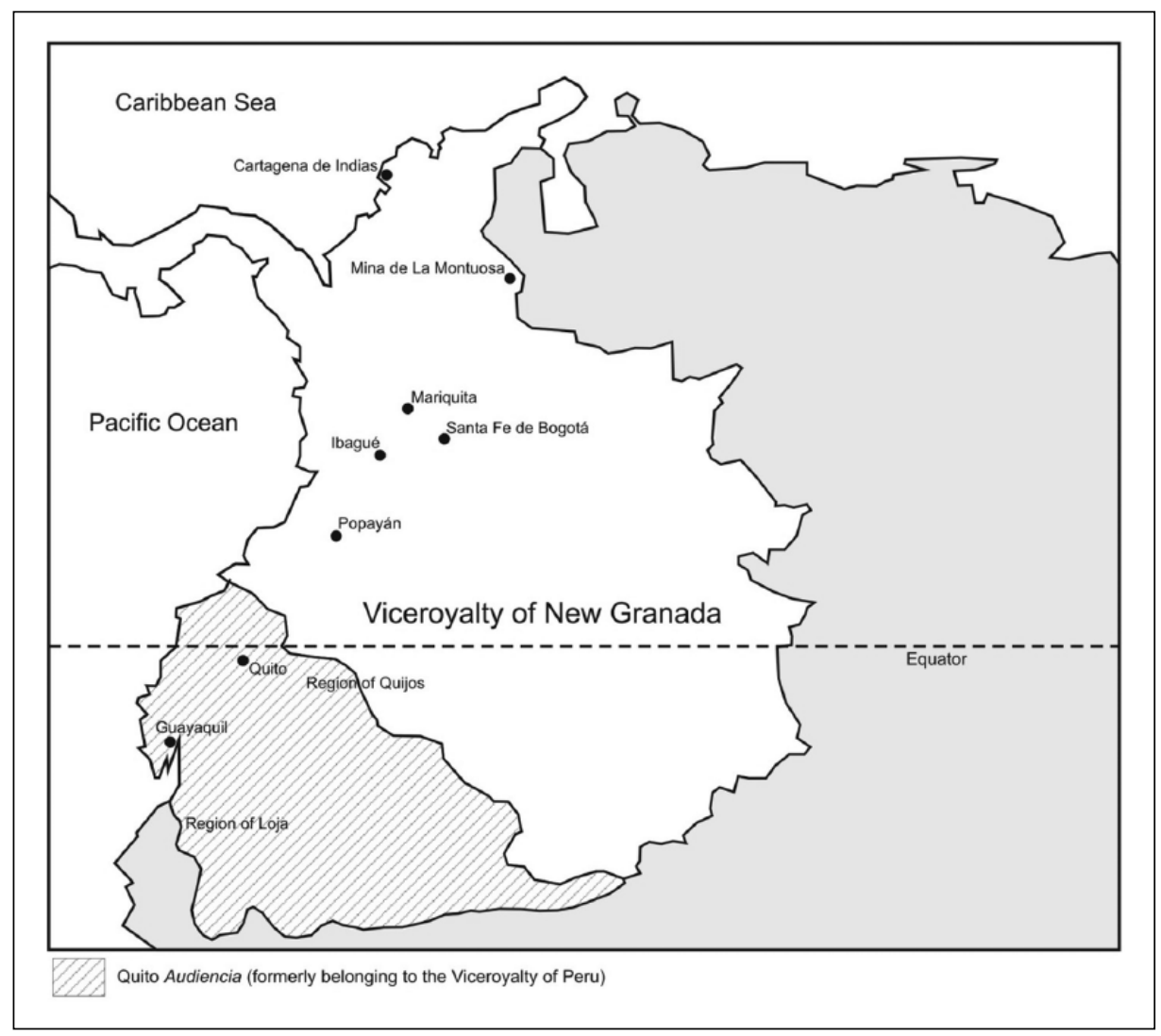

Figure I. Map of the Viceroyalty of New Granada.

flattery and interchange that sustained his vast network of contacts. On the other hand, the large number of illustrations - often presented as a sign of the growing success of the expedition - also served to mask what later would prove to be a fatal aspect of Mutis' managerial efforts: the lack of a clear sense on where to put an end to such a disproportionate project. Indeed, just as the exuberance of the New Granada flora constituted the central motivation underlying the expedition, its apparent incommensurability became a serious threat to the project's success. ${ }^{57}$ In other words, while too few illustrations of this vast botanical treasure would have made Mutis' project a failure, too many of them ended up rendering it unviable. In this respect, it would be unfair to put the blame on Mutis alone for what must ultimately be regarded as a rather disappointing outcome: instances of mismanagement occurred at various levels throughout the duration of the expedition. The lack of efficient supervision on the part of the local administration would be one case. The mildly concerned tolerance regarding the expedition's continuous delays on the part of the Spanish metropolitan authorities would be another.

These features of the New Granada expedition illustrate a case of clear imbalance between the practice of accumulation and the virtues of good management. For years the 
crown demanded that Mutis hand in the results of the expedition, obtaining nothing but missed deadlines and promises. Once Mutis died, and the War of Independence broke out, the conflict regarding the effective possession of the outcome of the expedition radicalized: who was to own Mutis' various businesses, his splendid library, the artistic workshop and, above all, the paper Flora, the great American treasure? The metropolis? The dissolved viceroyalty? The emerging nation? Or Mutis' nephew, Sinforoso, who had inherited the control of a truly 'family business'?

A similar problem of imbalance plagued the projects devoted to the three natural products mentioned above. Mutis could not make the tea of Bogotá profitable, neither was he able to set up an estanco of American cinnamon or quina - the 18th-century green chimera that was intended to replace the golden fantasies of the time of conquest. From both a managerial and financial perspective, the green reconquista was a sound failure, a 'broken dream' ${ }^{58}$ In this regard, Mutis' share of responsibility would be directly proportional to his ability (or lack thereof) to face the multifaceted nature of his commitments. These included securing prosperous businesses intended to enrich the royal and vice royal arks - 'for the benefit of mankind', as he insisted - while, at the same time, pursuing his own goals of prosperity and recognition. They also involved investing the meagre benefits obtained through his half-private, half-public ventures to pay the salaries of the painters working for his endless iconographic project. None of these tasks could be untangled from one another, or from the overall knowledge-making and commodification policies that motivated them. Their interconnection and interdependence give us a measure of the Hydra-like nature of Mutis' endeavours.

\section{Fertile management, sterile accumulation}

At the beginning of his account of the natural history of the malagueta (a type of American pepper) published in 1780, Casimiro Gómez Ortega wrote:

It is useless to possess the most benign and fertile territories in the world, if we do not attempt to profit from the natural products that they grant us, extending knowledge and consumption of them within the country, and fostering their extraction through free trade. Without these measures, the most expansive territories become sterile deserts, as useless to their colonists as to the metropole. ${ }^{59}$

A year before, the same author had insisted on a similar issue by claiming that 'the vegetable riches of Spanish America [...] have over the mineral ones the advantage that they can be propagated and multiplied ad infinitum once they are possessed and naturalized' ${ }^{60}$ This association between fertility, abundance and utility surely must be counted as one of the most recurrent themes in Spanish reformist thought. The New World, and its flora in particular, was seen as a prodigiously abundant and inexhaustible source of natural products. In the light of this potential wealth, the Spanish Enlightenment launched a number of initiatives to convert these natural resources into economic benefit. In this regard, the history of science, to a large extent, has privileged the social and relatively permanent aspects of these initiatives, focusing on the role of the state, the nation and institutions. However, as the case of Mutis and the New Granada expedition reveals, some projects devoted to the appropriation of the 
New World were centred around highly individualized and contingent ventures, functioning in accordance with dynamics that would not necessarily respond to the centreperiphery model. ${ }^{61}$ Indeed, the multiplicity of settings, the multi-directionality of movements, the variety of resonating and conflicting interests, even the ontological instability of the New Granada expedition itself - interpreted here as a centre occasionally 'on the move' - all these factors beg for a more dynamic and polycentric framework. ${ }^{62}$

In particular, the case of Mutis is a good example of the difficulties associated with the practice of accumulation and the challenges - epistemic, economic, socio-political posed by the plentiful American nature. Whether it was the amassing of stocks of quina, cinnamon and tea, or the carefully controlled compilation of mimetic capital for his Flora de Bogotá, Mutis' efforts to match the richness of American nature with the abundance of his own accumulating activities did not yield the expected results. Part of the answer lies in the fact that Mutis' accumulated goods did not circulate; they became static and, eventually, useless. The story of his managerial efforts, in this regard, illustrates the challenges of transportation and translation; that is, how to render the objects of accumulation mobile and potentially profitable; how to stabilize them and make them combinable. It illustrates Lissa Roberts' argument against the 'teleological orientation of Latour's depiction' of a geography of knowledge that seems too hierarchical and circumscribed to rigid divisions of labour. Instead, with all its elements of determination and mischance, the case of Mutis evokes 'moments of historical openness and contingency'. ${ }^{63}$

This could also apply to the more affirmative and successful outcomes of Mutis' project, the most important of which was the reinforcement of the scientific culture throughout the viceroyalty. Intellectual prowess and self-reliance would play a crucial role in the processes of political identity creation that eventually led to independence. In this regard, Mutis' project proved to be quite a fertile enterprise after all, especially in the eyes of a nationalist and Romantic historiography, which turned the Cadiz-born naturalist into a 'father figure' and a precursor of Colombian independence - a classic example of hagiographic reconstruction.

Similarly, the Flora de Bogotá project came to be interpreted as an epic undertaking, bound to the fate of the emerging nation. ${ }^{64} \mathrm{~A}$ particularly significant chapter of this narrative concerns the last episode in the story of the New Granada expedition materials. In August 1816, the Spanish general Pablo Morillo ordered the confiscation and shipment to Spain of all the Flora de Bogotá documents. In a few days, under the threat of the arms, Sinforoso Mutis and Francisco Javier Matis - 'the best painter of flowers in the world', according to Humboldt - packed the materials in 104 boxes and sent them to the Royal Botanical Garden in Madrid, where they are still kept today. ${ }^{65}$

In spite of this act of definitive appropriation, the botanical iconography of Mutis' workshop, invested with the singular aura of irreproducible works, was turned into a national icon, vindicated by the succeeding Colombian governments. By the 1950 s, as a definite sign of interest in recapitalizing on this 'green treasure', the Spanish and Colombian government reached an agreement to edit and publish these precious materials. Later in the century, the Colombian and Spanish authorities decided to print Mutis' portrait on the 200 peso and 2000 peseta notes respectively. We may consider it to be a result of the alchemy of time: 200 years after the assembling of the Flora de Bogotá, the symbolic capital had finally turned into cold cash. 


\section{Acknowledgement}

The authors would like to thank Lissa Roberts for her valuable comments in helping to improve this paper.

\section{Funding}

The authors would like to acknowledge the support of the Naturalezas figuradas Research Project (HAR2010-15099) and the Postdoctoral Grant Programme of the Basque Government.

\section{Notes}

1. Pedro Rodríguez Campomanes, Reflexiones sobre el comercio español a Indias, Vicente Llombart (ed.) (Madrid: Instituto de Estudios Fiscales, 1988). All translations are the authors' except where otherwise noted.

2. Campomanes, Reflexiones, p. 247.

3. Alajandro Malaspina, Plan de un viaje cientifico, Archivo del Museo Naval, Ms. 583, 5-7.

4. On these reformist policies see Gabriel B. Paquette, Enlightenment, Governance, and Reform in Spain and Its Empire, 1759-1808 (Basingstoke: Palgrave Macmillan, 2008).

5. 'The new wealth of the Americas suddenly turned "green"'. Jorge Cañizares-Esguerra, 'How Derivative Was Humboldt?', in Londa Schiebinger and Claudia Swan (eds.) Colonial Botany. Science, Commerce, and Politics in the Early Modern World (Philadelphia: University of Pennsylvania Press, 2005), p. 163. On the notion of 'green gold' underlying the 'green rush' and 'green treasure' expressions see Cañizares-Esguerra and Londa Schiebinger's chapters in Colonial Botany, as well as Paula de Vos, 'The Science of Spices: Empiricism and Economic Botany in the Early Spanish Empire', Journal of World History, 2006, 17(4), pp. 399-427.

6. Cited, with translation, in Neil Safier, Measuring the New World. Enlightenment Science and South America (Chicago: University of Chicago Press, 2008), p. 234.

7. The expressions 'El Dorado vegetal' or 'El Dorado verde' appear frequently in the literature, as in Francisco Javier Puerto, Ciencia de cámara. Casimiro Gómez Ortega (1741-1818), el cientifico cortesano (Madrid: Consejo Superior de Investigaciones Científicas, 1992), or Marcelo Frías, Tras El Dorado vegetal. José Celestino Mutis y la real expedición botánica del Nuevo Reino de Granada (1783-1808) (Sevilla: Diputación de Sevilla, 1994).

8. Mauricio Nieto, Remedios para el imperio. Historia natural y la apropiación del Nuevo Mundo (Bogotá: Instituto Colombiano de Antropología e Historia, 2000); English edition: Remedies for the Empire. The Eighteenth Century Spanish Botanical Expeditions to the New World (University of London, Ph.D. Dissertation, 1993).

9. Cited in Puerto, Ciencia de cámara, p. 156.

10. The bibliography on botanical expeditions in the Spanish Enlightenment is large. Important titles are Francisco Javier Puerto, La ilusión quebrada. Botánica, sanidad y política científica en la España Ilustrada (Madrid: Consejo Superior de Investigaciones Científicas, 1988); Manuel Sellés, José Luis Peset and Antonio Lafuente (eds.), Carlos III y la ciencia de la Ilustración (Madrid: Alianza, 1988); Antonio Lafuente and José Sala Catalá (eds.), Ciencia Colonial en América (Madrid: Alianza, 1992); Antonio Lafuente, 'Enlightenment in an Imperial Context: Local Science in the Late Eighteenth-Century Hispanic World', Osiris, 15, 2000, pp. 155-73; Nieto, Remedios para el imperio; Antonio Lafuente and Nuria Valverde, 'Linnaean Botany and Spanish Imperial Biopolitics', in Londa Schiebinger and Claudia Swan, Colonial Botany, pp. 134-48; Daniela Bleichmar, Visible Empire. Botanical Expeditions and Visual Culture in the Spanish Enlightenment (Chicago: University of Chicago Press, 2012).

11. Bruno Latour, Science in Action: How to Follow Scientists and Engineers through Society (Cambridge: Harvard University Press, 1987). 
12. On Mutis and the New Granada expedition the literature is also large. See Frías, Tras El Dorado vegetal, and José Antonio Amaya, Mutis, apóstol de Linneo. Historia de la botánica en el virreinato de la Nueva Granada (1760-1783) (2 vols, Bogotá: Instituto colombiano de antropología e historia, 2005). The aforementioned works by Nieto, Remedios para el imperio, and Bleichmar, Visible Empire, deal with Mutis' expedition extensively and in a highly innovative fashion, but their scope is much wider.

13. Cited in María de los Ángeles Calatayud, Pedro Franco Dávila. Primer Director del Real Gabinete de Historia Natural fundado por Carlos III (Madrid: CSIC - Museo Nacional de Ciencias Naturales, 1988), pp. 50-1.

14. On the term 'economic botany' see Schiebinger and Swan, Colonial Botany; and Vos, 'The Science of Spices'.

15. On this expedition see Simon Varey (ed.), The Mexican Treasury. The Writings of Dr. Francisco Hernández (Stanford CA: Stanford University Press, 2000) and Simon Varey, Rafael Chabrán and Dora V. Weiner (eds.), Searching for the Secrets of Nature. The Life and Works of Dr. Francisco Hernández (Stanford CA: Stanford University Press, 2000).

16. Lisbet Koerner, Linneaus: Nature and Nation (Cambridge MA: Harvard University Press, 1999).

17. See Nieto, Remedios para el imperio, ch. 2.

18. Edward O. Wilson and José M. Durán, Kingdom of Ants: José Celestino Mutis and the Dawn of Natural History in the New World (Baltimore: Johns Hopkins University Press, 2010).

19. Koerner, Linnaeus, p. 14.

20. Cited in Amaya, Mutis, vol. I, p. 73.

21. Amaya, Mutis; our emphasis.

22. We follow the use of this expression in Bleichmar, Visible Empire, ch. 1. On the role of the Royal Botanical Garden of Madrid, see Puerto, La ilusión quebrada.

23. See Jonathan Israel, Conflicts of Empires: Spain, the Low Countries, and the Struggle for World Supremacy, 1585-1713 (London: Hambledon, 1997).

24. For an up-to-date discussion of this subject see Matthew James Crawford, 'Empire's Experts: The Politics of Knowledge in Spain's Royal Monopoly of Quina (1751-1808)', Ph.D. dissertation, History Department, University of California - San Diego (2009). See also Miguel Ángel Puig-Samper, 'El oro amargo. La protección de los quinares americanos y los proyectos de estanco de la quina en Nueva Granada', in Manuel Lucena (ed.) El bosque ilustrado: Estudios sobre la politica forestal española en América (Madrid: Instituto Nacional para la Conservación de la Naturaleza- Instituto de la Ingeniería de España, 1991), pp. 219-40; Gonzalo Hernández de Alba, Quinas amargas, el sabio Mutis y la discusión naturalista del siglo XVII (Bogotá: Academia de Historia de Bogotá - Tercer Mundo Editores, 1996).

25. Safier, Measuring the New World, pp. 252-62.

26. Nieto, Remedios para el imperio, p. 198.

27. Nieto, Remedios para el imperio, pp. 183-232; Amaya, Mutis, 292-302; Frías, Tras El Dorado vegetal, pp. 159-211.

28. Mathew James Crawford, "A "Reasoned Proposal" against "Vain Science": Creole Negotiations of an Atlantic Medicament in the Audiencia of Quito (1776-92)', Atlantic Studies, 7(4), 2010, pp. 397-419, p. 413.

29. Crawford, 'A "Reasoned Proposal"', p. 400.

30. The reports by Santiesteban and López Ruiz were written in 1753 and 1784 respectively. Puig-Samper, 'El oro amargo', pp. 219-40.

31. Nieto, Remedios para el imperio, p. 203. 'Don Salvador Rizo, albacea del sabio Mutis y Mayordomo de la expedición botánica, explica las circunstancias del viaje a Cuba de Don Sinforoso Mutis y consecuencias del mismo', in Guillermo Hernández de Alba, Historia documental de la Real Expedición Botánica del Nuevo Reino de Granada 1808-1952 (Bogotá: 
Instituto Colombiano de Cultura Hispánica, 1986), pp. 157-60. In this document Rizo provides an account on how Sinforoso Mutis left in 1803, with instructions to collect specimens all the way to Cartagena, and leave the remaining stocks of quina in Cuba.

32. José Celestino Mutis, El Arcano de la quina (Burgos: Fundación de Ciencias de la Salud, 1994).

33. Cited in Nieto, Remedios para el imperio, p. 212.

34. The first reports on the Peruvian cinnamon go back to the 16th century. The Spanish physician Nicolás Monardes, for example, referred to it in his treatise Historia medicinal de las cosas que se traen de nuestras Indias occidentales (1574). In the 18th century, during the geodesic expedition to Perú, Joseph de Jussieu reported on the cinnamon, with the advice of the creole Pedro Maldonado. On their return trip, thanks to the collaboration of Bernard de Jussie, the descriptions of American cinnamon reached Lamarck, who named it laurus quixos.

35. On Cuéllar and the successive projects designed to exploit the Philippines see Javier Puerto, La ilusión quebrada; Belén Bañas, Una historia natural de Filipinas: Juan de Cuéllar, 17391801 (Barcelona: Ediciones del Serbal, 2000); Belén Bañas, Calinga. La canela en Filipinas en la segunda mitad del siglo XVIII (Madrid: Asociación Española de Estudios del Pacífico, 2001).

36. Frías, Tras El Dorado vegetal, p. 213.

37. Having referred to the 'mercantilist/free trade models' dichotomy, we should add that we agree with Lissa Roberts (see her contribution to this issue) on the risks of using this split categorization without problematizing the two models at stake and their in-between ramifications. Hence our emphasis on the elusive nature of these policies and their outcome, as well as on the multiplicity of agents involved, including the government. See Josep Delgado, Dinámicas imperiales (1650-1796). España, América y Europa en el cambio institucional del sistema colonial español (Barcelona: Edicions Bellaterra, 2007).

38. Puerto, Ciencia de cámara, p. 164.

39. For a similar case study see, in this volume, Lissa Roberts' discussion of the exploitation of nutmeg and cloves on the Isle of France.

40. Georg Simmel, Sociology. Inquiries into the Construction of Social Forms (2 vols, Boston: Brill, 2009).

41. Carmen Sotos Serrano, 'Aspectos artísticos de la Real Expedición Botánica de Nueva Granada', in María Pilar de San Pío (ed.) Mutis y la Real Expedición Botánica del Nuevo Reino de Granada (2 vols, Barcelona: Lunwerg, 1992), vol. 1, pp. 121-57, p. 121. As this author indicates, it is difficult to estimate the total number of illustrations, since many were produced and sent by Mutis to his correspondents.

42. In addition to the aforementioned Works by Nieto, Remedios para el imperio; Frías, Tras El Dorado vegetal; and Sotos Serrano, 'Aspectos artísticos'; see Lorenzo Uribe, 'Los Maestros Pintores', in Flora de la Real Expedición Botánica del Nuevo Reino de Granada (1783-1816) (50 vols, Madrid: Ediciones Cultura Hispánica, 1954), vol. I, pp. 102-6, and José Antonio Amaya and Miguel Ángel Puig-Samper (eds.), Mutis al natural. Ciencia y arte en el Nuevo Reino de Granada (Bogotá: Museo Nacional de Colombia, 2008).

43. This is the main thesis in her recent book, Visible Empire. We are grateful to Daniela Bleichmar for allowing us to read a prepublication version of this work. Also by her, other important texts on Mutis and the Royal Botanical Expedition to New Granada are: 'Painting as Exploration: Visualizing Nature in Eighteenth-Century Colonial Science', Colonial Latin American Review 15(1), 2006, pp. 81-104; 'Atlantic Competitions: Botanical Trajectories in the Eighteenth-Century Spanish Empire', in James Delbourgo and Nicholas Dew (eds.) Science and Empire in the Atlantic World (New York: Routledge, 2007), pp. 225-52; “"A Visible and Useful Empire": Visual Culture and Colonial Natural History in the Eighteenth-century 
Spanish World', in Daniela Bleichmar, Paula De Vos, Kristin Huffine and Kevin Sheehan (eds.) Science in the Spanish and Portuguese Empires, 1500-1800 (Stanford CA: Stanford University Press, 2009), pp. 290-310; 'The Geography of Observation: Distance and Visibility in Eighteenth-Century Botanical Travel', in Lorraine Daston and Elizabeth Lunbeck (eds.) Histories of Scientific Observation (Chicago: University of Chicago Press, 2011), pp. 373-95.

44. Bleichmar, Visible Empire, pp. 103-22. For a general survey on this subject see Brian J. Ford, 'Scientific Illustration in the Eighteenth Century', in Roy Porter (ed.) The Cambridge History of Science, Vol. 4: Eighteenth-Century Science (Cambridge: Cambridge University Press, 2003), pp. 561-83. For a thorough analysis of eighteenth-century image-making strategies see also Lorraine Daston and Peter Galison, Objectivity (New York: Zone Books, 2007).

45. Bleichmar, 'The Geography of Observation', p. 382; Sotos Serrano, 'Aspectos artísticos', p. 133.

46. Cited in Sotos Serrano, 'Aspectos artísticos', p. 134, note 15; Guillermo Hernández de Alba (ed.), Archivo epistolar del sabio naturalista José Celestino Mutis (4 vols, Bogotá: Presencia, 1983), vol. I, pp. 114-15.

47. Sotos Serrano, 'Aspectos artísticos', pp. 141-2.

48. 'It has been easier, and always will be, to manage people who are more docile, even if they are less skilled, because I provide through training the skills they lack at the beginning, and in this way I can compensate for the lack of docility of the Spanish artists, who always perform poorly in America'. Cited, with translation, in Bleichmar, Visible Empire, p. 89; Hernández de Alba, Archivo epistolar, vol. I, p. 313.

49. With the exception of two painters coming from Spain - whose performance Mutis found rather disappointing - most artists originated from the Quito Audiencia or New Granada. See Bleichmar, Visible Empire, pp. 84-90.

50. It may be worth mentioning that Mutis had initially conceived the Flora de Bogotá as the first part of a much larger natural history of the New World. According to his plan, New Granada was simply meant to be a first chapter. In fact, the original working title of the Florae Bogotensis had been Florae Americanae.

51. Bleichmar, Visible Empire, p. 89.

52. 'If I am not deceived by my own passion [...] I can promise myself that any image coming from my hands will not need any retouching by those who come after me, and any botanist in Europe will find represented in it the finest characters of fructification, which are the a-b-c of science - of botany in the Linnaean sense - without the need to come see them in their native ground'. Quoted, with translation, in Bleichmar, Visible Empire, p. 119; Hernández de Alba, Archivo epistolar, vol. I, pp. 439-40. On long-distance collective empiricism in connection with Mutis, see Bleichmar, 'The Geography of Observation'.

53. Stephen Greenblatt, Marvellous Possessions. The Wonder of the New World (Chicago, 1991), p. 6.

54. Karl Marx, Capital: Critique of Political Economy, trans. by Ben Fowkes (3 vols, London: Penguin Books in association with New Left Review, 1976), esp. Part 8.

55. Greenblatt, Marvellous Possessions, p. 6.

56. Greenblatt, Marvellous Possessions, p. 120.

57. On the question of managing large amounts of information, even if is not specifically focused on the 'illustration overload' issue that concerns us here, see Ann Blair, Too Much to Know: Managing Scholarly Information Before the Modern Age (New Haven: Yale University Press, 2010).

58. This is the title of Javier Puerto's book on the Botanic Garden and the scientific expeditions to America; La ilusión quebrada.

59. Cited, with translation, in Bleichmar, Visible Empire, p. 31; original quotation in Casimiro Gómez Ortega, Historia natural de la malagueta ó pimienta de tavasco, y Noticia de los usos, 
virtudes y exención de derechos de esta saludable y gustosa especia, con la lámina de su árbol (Madrid: D. Joachin Ibarra, 1780), pp. 1-2.

60. Cited, with translation, in Bleichmar, Visible Empire, p. 31; original quotation in Casimiro Gómez Ortega, Instrucción sobre el modo más seguro y económico de transportar plantas vivas por mar y tierra a los países más distantes (Madrid: D. Joachin Ibarra, 1779), p. 22.

61. For a classification of Hispanic expeditions which challenged the centre-periphery model in order to discuss the initiatives of the viceroyalties and the church on equal terms with those of the metropolis, see Antonio Lafuente and Leoncio López-Ocón, 'Scientific Traditions and Enlightenment Expeditions in Eighteenth Century Hispanic America', in Juan José Saldaña (ed.) Science in Latin America. A history (Austin: University of Texas Press, 2006), pp. 123-50.

62. Latour, Science in Action. For a discussion of Latour's model see Lissa Roberts, 'Centres and Cycles of Accumulation', in Lissa Roberts (ed.) Centres and Cycles of Accumulation In and Around the Netherlands During the Early Modern Period (Zurich: Lit, 2011), pp. 3-27.

63. Roberts, 'Centres and Cycles of Accumulation', p. 6.

64. Several members of the New Granada expedition actively took part in the revolts that led to the War of Independence. In 1816 Salvador Rizo, director of the artistic workshop and Mutis' mayordomo, was executed by the royal army. The astronomer and engineer Francisco José de Caldas, one of the most prominent figures in the American Enlightenment met the same fate.

65. Hernández de Alba, Archivo epistolar, p. 309, transcribes the incidents during the Morillo commission, aimed at writing inventories and packing things, from collection pieces to books: 'Era un verdadero Museo de Historia Natural del país: cuadrúpedos, aves, reptiles e insectos raros, objetos preciosos del reino mineral, colecciones de maderas, muestras de cristal de roca, de oro y platino (...) afortunadamente entre los prisioneros aristócratas estaba el doctor (Sinforoso) Mutis'. 